\title{
Assessment of the teaching-learning process in students of the health area: cardiopulmonary resuscitation maneuvers*
}

\author{
Avaliação do processo ensino-aprendizagem de estudantes da área \\ da saúde: manobras de ressuscitação cardiopulmonar \\ Evaluación del proceso enseñanza-aprendizaje de estudiantes del \\ área de salud: maniobras de resucitación cardiopulmonar
}

Patrícia Moita Garcia Kawakame ${ }^{1}$, Ana Maria Kazue Miyadahira²

\footnotetext{
* Extracted from the thesis "Avaliação do Processo Ensino-aprendizagem dos estudantes de graduação da área de saúde: manobras para ressuscitação cardiopulmonar com desfibrilador externo automático", Escola de Enfermagem, Universidade de São Paulo, 2011.

${ }^{1}$ Universidade Federal do Mato Grosso do Sul, Campo Grande, MS, Brazil.

${ }^{2}$ Universidade de São Paulo, Escola de Enfermagem, São Paulo, SP, Brazil.
}

\begin{abstract}
Objective: To evaluate the skills and knowledge of undergraduate students in the health area on cardiopulmonary resuscitation maneuvers with the use of an automatic external defibrillator. Method: The evaluation was performed in three different stages of the teaching-learning process. A theoretical and practical course was taught and the theoretical classes included demonstration. The evaluation was performed in three different stages of the teaching-learning process. Two instruments were applied to evaluate the skills (30-items checklist) and knowledge (40-questions written test). The sample comprised 84 students. Results: After the theoretical and practical course, an increase was observed in the number of correct answers in the 30-items checklist and 40-questions written test. Conclusion: After the theoretical class (including demonstration), only one of the 30 -items checklist for skills achieved an index $\geq 90 \%$ of correct answers. On the other hand, an index of correct answers greater than $90 \%$ was achieved in $26(86.7 \%)$ of the 30 items after a practical training simulation, evidencing the importance of this training in the defibrillation procedure.
\end{abstract}

\section{DESCRIPTORS}

Cardiopulmonary Resuscitation; Defibrillators; Students, Health Occupations; Health Education; Learning; Evaluation. 


\section{INTRODUCTION}

In the last years, advances have been observed in relation to prevention and training in cardiopulmonary resuscitation (CPR). In addition, defibrillation became accessible to the public by law, with mandatory availability of automated external defibrillator (AED) in public places. However, many lives lost every year in Brazil are related to cardiopulmonary arrest (CPA). According to the Brazilian Society of Cardiology, about 200,000 CPAs per year are estimated to occur in Brazil. Half of them occur in hospitals, and the other half outside hospitals ${ }^{(1)}$.

Regarding Basic Life Support (BLS), it is known that the presence of a trained rescuer is the main determinant for the survival of victims of CPA. However, the little knowledge and skills of most students in the health area on this topic is notorious and makes concern. Thus, the literature indicates that early exposure of these students to this procedure would be appropriate, i.e., these skills should be promoted early in the course and reinforced in the following years ${ }^{(2)}$.

We emphasize that training in CPR should provide conditions for a good development of the psychomotor skills necessary to apply this technique, in addition to transmitting knowledge on the technical procedure. Thus, evaluation of such trainings guided by pre-established criteria is essential ${ }^{(3)}$.

With regard to training, we also emphasize the use of simulation strategies, as they are on the rise in the health area, in a prominent position among the tools for teaching and evaluation ${ }^{(4)}$. Simulation technologies provide an improvement in practical training, with a great potential for shaping education in the health $\operatorname{area}^{(5)}$.

In this scenario, the possibility of using simulation as a teaching strategy for training in the assistance to victims of cardiopulmonary arrest (CPA), by means of cardiopulmonary resuscitation $(\mathrm{CPR})$ and with the use of the automatic external defibrillator (AED), for students who are beginning an undergraduate course in the health area was strongly attractive to this research.

Although the objective of this research was to offer a theoretical and practical course (with theoretical class and practical training) for students to attend people with CPA, we asked the following question. Could such a course, which is based on a standard model of development of CPR maneuvers with the use of AED, provide both psychomotor skills and knowledge necessary to fresh students in the health area?

In order to answer this question, this study not only have trained students in the health area but also evaluated the teaching-learning process related to the CPR maneuvers using AEDs. Thus, the processes that underlie learning of motor and cognitive abilities were analyzed as both lead their performances in the activity.

In order that the teaching-learning process be an instrument in the theory-practice articulation, evaluation of training programs is important, as accurate indicators of past actions and restructuring of future actions are not obtained without evaluation of results ${ }^{(6)}$.

Therefore, this study was performed to evaluate the performance of undergraduate students in the health ar- ea in their SKILLS (practice) in the use of an AED and KNOWLEDGE (theory) about CPR maneuvers. The teaching activities were taken as stages: theoretical class (Stage 1), practical demonstration with a mannequin (Stage 2 ), and practical training simulation (Stage 3). Evaluations were performed before and after the theoretical class, including practical demonstration with mannequin $\left(1^{\text {st }}-2^{\text {nd }}\right.$ stage); before and after practical training simulation $\left(2^{\text {nd }}-3^{\text {rd }}\right.$ stage); and before and after theoretical class, including practical demonstration with mannequin and practical training simulation $\left(1^{\text {st }}-3^{\text {rd }}\right.$ stage $)$.

\section{METHOD}

\section{INSTITUTION}

This research was performed in a public private-law educational institution, in a municipality in the northwest region of the State of São Paulo (SP).

\section{Population/Sample}

In this study, the sample included 84 students (population: 518 first-year students)of undergraduate courses in the health area. The Proportional-Stratified Sampling technique was used to establish the sample size and specify how many elements should come from each course. As a result, the sample was composed of students from the Nursing (19), Pharmacy (31), Phonoaudiology (10), Physiotherapy (9), Psychology (10), and Biomedicine (5) courses.

\section{Data collection}

In order to assess the students SKILLS (practice) in CPR maneuvers with the use of AED in the teachinglearning process, a standard model in a checklist format was prepared to evaluate the execution of the 30 -item list. Its contents were based on the international guidelines for Cardiovascular Emergencies and Cardiopulmonary Resuscitation, as established by the International Liaison Committee on Resuscitation (ILCOR).After the researcher prepared the evaluation tools, a group of nine health professionals (body of judges), who were physicians and nurses specialists in Emergency or Intensive Care and acted in teaching, research, or assistance in health services, were asked to judge the composition, distribution of items in the respective aspects, and score the tools.

An instrument in the theoretical test format with objective questions (40 multiple-choice tests) was also used to assess the KNOWLEDGE (theory) about CPR maneuvers with the use of AED in the teaching-learning process.

\section{Operationalization}

After authorization by the Institution and Research Ethics Committee (CEP) Escola de Enfermagem, Universidade de São Paulo (EEUSP; protocol No 801/2009/ CEP), operationalization of data collection was initiated. The data were collected by the researcher in three stages using the previously described instruments. In Stage 1, a pre-test was performed before any intervention; in Stage 2, 
a first post-test was performed after teaching a theoretical class and offering a CPR demonstration with the use of AED in a mannequin; and in Stage 3, a second post-test was performed after offering a simulated practical training of CPR with the use of AED.

\section{Statistical treatment}

In the evaluation of the teaching-learning process, the $\mathrm{McNemar}$ test was used in the Assessment of both Practice (SKILLS) and Theory (KNOWLEDGE) to test the differences observed between stages. The Wilcoxon signed rank test was used to check the average scores obtained in the theoretical and practical evaluations and its relationship with the various aspects of the procedure.

\section{RESULTS}

Table 1 - Distribution of correct answers given by students in the three-stage execution of CPR maneuvers using the AED, according to the items and the respective aspects assessing SKILLS (practice) - Fernandópolis, SP, Brazil, 2010.

\begin{tabular}{|c|c|c|c|c|c|c|c|}
\hline \multirow{2}{*}{$\begin{array}{l}\text { Aspects of the } \\
\text { procedure }\end{array}$} & \multirow{2}{*}{ Items } & \multicolumn{2}{|c|}{ Stage 1} & \multicolumn{2}{|c|}{ Stage 2} & \multicolumn{2}{|c|}{ Stage 3} \\
\hline & & $\mathbf{N}^{o}$ & $\%$ & $\mathrm{~N}^{\mathbf{o}}$ & $\%$ & $\mathrm{~N}^{\mathbf{o}}$ & $\%$ \\
\hline \multirow{7}{*}{$\begin{array}{l}\text { Preliminary } \\
\text { steps }\end{array}$} & 1 & 12 & $(14.2)$ & 74 & $(88.1)$ & 83 & (98.8) \\
\hline & 2 & 12 & $(14.2)$ & 74 & $(88.1)$ & 83 & (98.8) \\
\hline & 3 & 8 & $(9.5)$ & 67 & (79.7) & 84 & $(100.0)$ \\
\hline & 4 & 2 & $(2.3)$ & 65 & $(77.3)$ & 84 & (100.0) \\
\hline & 5 & 70 & (83.3) & 76 & $(90.4)$ & 83 & (98.8) \\
\hline & 6 & 72 & (85.7) & 66 & (78.5) & 83 & (98.8) \\
\hline & 7 & 4 & $(4.7)$ & 63 & $(75.0)$ & 83 & (98.8) \\
\hline \multirow{2}{*}{$\begin{array}{l}\text { Opening of the } \\
\text { airways }\end{array}$} & 8 & - & - & 50 & $(59.5)$ & 82 & (97.6) \\
\hline & 9 & 6 & $(7.1)$ & 42 & $(50.0)$ & 80 & $(95.2)$ \\
\hline \multirow{4}{*}{ Ventilation } & 10 & - & - & 27 & $(32.1)$ & 78 & (92.8) \\
\hline & 11 & - & - & 23 & $(27.3)$ & 73 & (86.9) \\
\hline & 12 & 1 & (1.1) & 37 & $(44.0)$ & 72 & $(85.7)$ \\
\hline & 13 & - & - & 23 & $(27.3)$ & 82 & (97.6) \\
\hline \multirow{9}{*}{$\begin{array}{l}\text { Chest } \\
\text { compressions }\end{array}$} & 14 & 4 & $(4.7)$ & 40 & $(47.6)$ & 84 & $(100.0)$ \\
\hline & 15 & 7 & $(8.3)$ & 62 & (73.8) & 84 & $(100.0)$ \\
\hline & 16 & 4 & $(4.7)$ & 25 & $(29.7)$ & 82 & (97.6) \\
\hline & 17 & 6 & $(7.1)$ & 45 & $(53.5)$ & 83 & (98.8) \\
\hline & 18 & 2 & $(2.3)$ & 44 & $(52.3)$ & 80 & (95.2) \\
\hline & 19 & 1 & $(1.1)$ & 26 & (30.9) & 79 & $(94.0)$ \\
\hline & 20 & 1 & $(1.1)$ & 59 & $(70.2)$ & 82 & (97.6) \\
\hline & 21 & - & - & 64 & $(76.1)$ & 73 & (86.9) \\
\hline & 22 & - & - & 52 & (61.9) & 74 & $(88.1)$ \\
\hline \multirow{8}{*}{ Use of EAD } & 23 & - & - & 59 & $(70.2)$ & 84 & $(100.0)$ \\
\hline & 24 & - & - & 46 & $(54.7)$ & 78 & $(92.8)$ \\
\hline & 25 & - & - & 61 & $(72.6)$ & 82 & (97.6) \\
\hline & 26 & - & - & 53 & $(63.1)$ & 84 & $(100.0)$ \\
\hline & 27 & - & - & 56 & $(66.6)$ & 84 & $(100.0)$ \\
\hline & 28 & - & - & 54 & $(64.2)$ & 84 & (100.0) \\
\hline & 29 & - & - & 41 & $(48.8)$ & 84 & (100.0) \\
\hline & 30 & - & - & 42 & $(50.0)$ & 84 & $(100.0)$ \\
\hline
\end{tabular}

According to Table 1, no item with index of correct answers $\geq \mathbf{9 0 \%}$ was observed in Stage 1. In Stage 2, after the theoretical class with practical demonstration, only one item presented correct answers with an index $>\mathbf{9 0 \%}$ (76 students; 90.4\%). Correct answers in all the other items of the instrument had an index $<\mathbf{9 0 \%}$. In Stage 3, after the simulated practical training, 26 items had correct answers with an index $>90 \%$.In the $\mathbf{1}^{\text {st }}-3^{\text {rd }}$ stage, we also observed that 84 (100\%) students showed a statistically significant increase in their scores in all aspects of the procedure(preliminary steps, ventilation, compressions, and AED use).

Table 2 - Distribution of students' correct answers in the threestage of solving questions, according to the items and the respective aspects of the procedure in assessing KNOWLEDGE (theory) -Fernandópolis, SP, Brazil, 2010.

\begin{tabular}{|c|c|c|c|c|c|c|c|}
\hline \multirow{2}{*}{$\begin{array}{l}\text { Aspects of the } \\
\text { procedure }\end{array}$} & \multirow{2}{*}{ Questions } & \multicolumn{2}{|c|}{ Stage 1} & \multicolumn{2}{|c|}{ Stage 2} & \multicolumn{2}{|c|}{ Stage 3} \\
\hline & & $\mathbf{N}^{\mathbf{o}}$ & $\%$ & $\mathbf{N}^{\mathbf{o}}$ & $\%$ & $\mathrm{~N}^{\mathbf{0}}$ & $\%$ \\
\hline Preliminary steps & 1 & 38 & $(45.2)$ & 80 & $(95.2)$ & 77 & $(91.6)$ \\
\hline Preliminary steps & 2 & 26 & (30.9) & 77 & (91.6) & 75 & $(89.2)$ \\
\hline Preliminary steps & 3 & 32 & (38.1) & 78 & $(92.8)$ & 78 & $(92.8)$ \\
\hline Preliminary steps & 4 & 29 & $(34.5)$ & 81 & $(96.4)$ & 67 & $(79.7)$ \\
\hline Preliminary steps & 5 & 66 & $(78.5)$ & 82 & $(97.6)$ & 80 & $(95.2)$ \\
\hline Ventilation & 6 & 23 & $(27.3)$ & 76 & $(90.4)$ & 78 & $(92.8)$ \\
\hline Preliminary steps & 7 & 32 & (38.1) & 48 & $(57.1)$ & 60 & $(71.4)$ \\
\hline Preliminary steps & 8 & 25 & $(29.7)$ & 80 & $(95.2)$ & 75 & $(89.2)$ \\
\hline Preliminary steps & 9 & 17 & $(20.2)$ & 82 & $(97.6)$ & 82 & $(97.6)$ \\
\hline Preliminary steps & 10 & 12 & $(14.2)$ & 65 & $(77.3)$ & 73 & $(86.9)$ \\
\hline $\begin{array}{l}\text { Opening of the } \\
\text { Airways }\end{array}$ & 11 & 39 & $(46.4)$ & 76 & $(90.4)$ & 79 & $(94.0)$ \\
\hline $\begin{array}{l}\text { Opening of the } \\
\text { Airways }\end{array}$ & 12 & 51 & $(60.7)$ & 80 & $(95.2)$ & 75 & $(89.2)$ \\
\hline $\begin{array}{l}\text { Opening of the } \\
\text { Airways }\end{array}$ & 13 & 17 & $(20.2)$ & 70 & $(83,3)$ & 70 & $(83.3)$ \\
\hline Ventilation & 14 & 14 & $(16.6)$ & 77 & $(91.6)$ & 76 & $(90.4)$ \\
\hline Ventilation & 15 & 24 & $(28.5)$ & 74 & $(88.1)$ & 82 & $(97.6)$ \\
\hline Ventilation & 16 & 39 & $(46.4)$ & 73 & $(86.9)$ & 77 & $(91.6)$ \\
\hline $\begin{array}{l}\text { Chest } \\
\text { Compressions }\end{array}$ & 17 & 38 & $(45.2)$ & 49 & $(58.3)$ & 71 & $(84.5)$ \\
\hline Ventilation & 18 & 16 & $(19.0)$ & 69 & $(82.1)$ & 41 & $(48.8)$ \\
\hline Ventilation & 19 & 38 & $(45.2)$ & 53 & $(63.1)$ & 58 & $(69.0)$ \\
\hline Preliminary steps & 20 & 37 & $(44.0)$ & 76 & $(90.4)$ & 79 & $(94.0)$ \\
\hline $\begin{array}{l}\text { Chest } \\
\text { Compressions }\end{array}$ & 21 & 9 & $(10.7)$ & 69 & $(82.1)$ & 67 & $(79.7)$ \\
\hline Preliminary steps & 22 & 52 & (61.9) & 65 & $(77.3)$ & 65 & $(77.3)$ \\
\hline Use of AED & 23 & 35 & $(41.6)$ & 82 & $(97.6)$ & 77 & $(91.6)$ \\
\hline $\begin{array}{l}\text { Chest } \\
\text { Compressions }\end{array}$ & 24 & 35 & $(41.6)$ & 78 & $(92.8)$ & 75 & $(89.2)$ \\
\hline $\begin{array}{l}\text { Chest } \\
\text { Compressions }\end{array}$ & 25 & 47 & $(55.9)$ & 77 & $(91.6)$ & 73 & $(86.9)$ \\
\hline $\begin{array}{l}\text { Chest } \\
\text { Compressions }\end{array}$ & 26 & 9 & $(10.7)$ & 74 & $(88.1)$ & 69 & $(82.1)$ \\
\hline $\begin{array}{l}\text { Chest } \\
\text { Compressions }\end{array}$ & 27 & 15 & $(17.8)$ & 78 & $(92.8)$ & 77 & $(91.6)$ \\
\hline $\begin{array}{l}\text { Chest } \\
\text { Compressions }\end{array}$ & 28 & 24 & $(28.5)$ & 76 & $(90.4)$ & 72 & $(85.7)$ \\
\hline Use of AED & 29 & 13 & $(15.4)$ & 78 & $(92.8)$ & 75 & $(89.2)$ \\
\hline Preliminary steps & 30 & 29 & $(34.5)$ & 68 & $(80.9)$ & 67 & $(79.7)$ \\
\hline
\end{tabular}

continued... 
...continuation

\begin{tabular}{lcccccccc}
\hline \multirow{2}{*}{$\begin{array}{l}\text { Aspects of the } \\
\text { procedure }\end{array}$} & \multirow{2}{*}{ Questions } & \multicolumn{3}{c}{ Stage 1 } & \multicolumn{3}{c}{ Stage 2 } & \multicolumn{3}{c}{ Stage 3 } \\
\cline { 2 - 8 } & & $\mathbf{N}^{\mathbf{0}}$ & $\%$ & $\mathbf{N}^{\mathbf{0}}$ & $\%$ & $\mathbf{N}^{\mathbf{o}}$ & $\%$ \\
\hline Use of AED & 31 & 59 & $(70.2)$ & 81 & $(96.4)$ & 83 & $(98.8)$ \\
Use of AED & 32 & 32 & $(38.1)$ & 67 & $(79.7)$ & 79 & $(94.0)$ \\
Use of AED & 33 & 15 & $(17.8)$ & 80 & $(95.2)$ & 78 & $(92.8)$ \\
Use of AED & 34 & 25 & $(29.7)$ & 82 & $(97.6)$ & 80 & $(95.2)$ \\
Preliminary steps & 35 & 35 & $(41.6)$ & 76 & $(90.4)$ & 74 & $(88.1)$ \\
Use of AED & 36 & 29 & $(34.5)$ & 76 & $(90.4)$ & 72 & $(85.7)$ \\
Use of AED & 37 & 18 & $(21.4)$ & 78 & $(92.8)$ & 75 & $(89.2)$ \\
Use of AED & 38 & 13 & $(15.4)$ & 76 & $(90.4)$ & 71 & $(84.5)$ \\
Preliminary steps & 39 & 26 & $(30.9)$ & 70 & $(83.3)$ & 75 & $(89.2)$ \\
Preliminary steps & 40 & 37 & $(44.0)$ & 74 & $(88.1)$ & 72 & $(85.7)$ \\
\hline
\end{tabular}

Regarding the index of correct answers (Table 2), no item had values $\geq 90 \%$ in Stage 1, 25 questions had values > $90 \%$ after theoretical class with demonstration in Stage 2, and 16 questions had values $>90 \%$ in Stage 3, i.e. after the simulated practical training. In the $\mathbf{1}^{\text {st }}-3^{\text {rd }}$ stage, a statistically significant increase was observed in the number of students (> 90\%) who increased their scores in the use of AED (84; 100\%), chest compressions $(83 ; 98.82 \%)$, preliminary steps $(82 ; 97.62 \%)$ and ventilation $(80 ; 95.23 \%)$ aspects.

Table 3 - Distribution of average scores obtained by students in the $1^{\text {st }}-3^{\text {rd }}$ stage in each aspect of the procedure in assessing SKILLS (practice) after the theoretical class and practical training -Fernandópolis, SP, Brazil, 2010.

\begin{tabular}{lccc}
\hline \multirow{2}{*}{ Aspects of the procedure } & \multicolumn{2}{c}{ Mean values } & Wilcoxon \\
\cline { 2 - 3 } & Stage $\mathbf{1}$ & Stage $\mathbf{3}$ & p values \\
\hline Preliminary steps & 19.64 & 67.42 & 0.0001 \\
Opening of the air ways & 0.71 & 19.28 & 0.0001 \\
Ventilation & 0.11 & 36.30 & 0.0001 \\
Chest compression & 2.90 & 84.84 & 0.0001 \\
Use of the AED & - & 74.92 & 0.0001 \\
Global mean values & 23.38 & 282.79 & 0.0001 \\
\hline
\end{tabular}

In Table 3, a significant difference was observed between the scores of students in assessing SKILLS (practice) in all aspects at the $1^{\text {st }}$ and $3^{\text {rd }}$ stages after the theoretical class and practical training $(\mathrm{p}=0.0001)$. A 0.05 significance level was considered in the Wilcoxon signed rank test.

Table 4 - Distribution of mean values of students' score in every aspect of the procedure in the $1^{\text {st }}-3^{\text {rd }}$ stage after the theoretical class and practical training in assessing KNOWLEDGE (theory) Fernandópolis, SP, Brazil, 2010.

\begin{tabular}{lccc}
\hline \multirow{2}{*}{ Aspects of the procedure } & \multicolumn{2}{c}{ Mean values } & Wilcoxon \\
\cline { 2 - 3 } & Stage $\mathbf{1}$ & Stage $\mathbf{3}$ & p values \\
\hline Preliminary steps & 1.46 & 3.27 & 0.0001 \\
Opening of the airways & 0.31 & 0.66 & 0.0001 \\
Ventilation & 0.45 & 1.22 & 0.0001 \\
Chest compression & 0.52 & 1.50 & 0.0001 \\
Use of the AED & 0.71 & 2.05 & 0.0001 \\
Global mean values & 3.48 & 8.71 & 0.0001 \\
\hline
\end{tabular}

In Table 4, we conclude that there is a significant difference between the students' score in assessing KNOWLEDGE (theory) in all aspects at the $1^{\text {st }} 3^{\text {rd }}$ stage after the theoretical class and practical training $(p=0.0001)$. A 0.05 significance level was considered in the Wilcoxon signed rank test.

\section{DISCUSSION}

In this research, the results of student's performance in CPR maneuvers with use of AED led us to infer that both cognitive and motor learning,as verified by assessing knowledge (theory) and abilities (practice), respectively, has occurred.

Similar data were found in a research performed in the School of Nursing, University of São Paulo, to evaluate a program for undergraduate students who were trained in CPR and use of defibrillator. The program involved a theoretical course, including practical demonstration of CPR maneuvers and use of defibrillator, individual practical training, and theoretical and practical evaluation, which was performed in only two steps. Regarding performance of students in the practical evaluation, they had an average score of 26.4 points in Stage 1, increasing to 252.8 in Stage 2. As for the theoretical evaluation, they had an average score of 3.06 points in Stage 1, increasing to 9.0 in Stage $2^{(7)}$.

Studies involving training in CPR have also been made to students in the high school, as highlighted in the study performed by researchers from the Universidade Federal de Alagoas, who compared the prior knowledge and the degree of early and late learning among students in public and private high schools with thirty students in each school. Before training, most students had insufficient knowledge about $\mathrm{CPR}$ and AED. After the course on BLS, a significant improvement was observed in both early and late learning of the students, especially in those in the private school ${ }^{(8)}$.

In evaluating these studies, the final product is undoubtedly satisfying and important, and our results were similar to those of this research. However, emphasizing some steps that precede the result and highlight the importance of practical training, as part of the theoretical and practical course offered to students, is essential in this discussion.

During evaluation of the students, they scored on some items still in Stage 2 of the study after theoretical class with practical demonstration (i.e., without having undergone a practical training). However, according to the results of this research in this scenario, rescuing that their performances were permeated with errors in the performance of their psychomotor skills is relevant. It was executed irregularly, uncertainly, and out of pace. In addition, we believe that students ignore how to improve their performances, although they can realize their mistakes while carrying out their activities. These results evidence that theoretical classes with demonstration of practice alone were not enough for the students to develop the psychomotor skills used in the CPR. Supplementing these activities with practical training would be necessary for the index of correct answers to be $>90 \%$. 
While accessing the literature, we noticed that studies like this have been conducted worldwide, and our results are similar to those in these studies.

It is worth mentioning a study performed in India with 42 students (first year of Medicine), who were evaluated for their knowledge and skills before and after a lecture with demonstration and practical training with simulators related to the basic life support (BLS). Assessment of skills showed that only $7 \%$ of students performed the steps correctly after they were submitted to the lecture with demonstration, and $74 \%$ of them performed the steps correctly after practical training. This evidenced that the program provided knowledge and proper practical skills to students in $\mathrm{BLS}^{(2)}$.

In a study performed in Greece, acquisition of skills and knowledge were also assessed. After a CPR course based on the guidelines of the European Resuscitation Council (ERC), written and practical tests were applied to 80 people who were trained and evaluated at the end of the course at intervals of one, three, and six months. Although other variables such as retention, previous education level, and age have been studied, it was evidenced that there was learning, which has improved over time, as people were exposed to practical training, and the lowest score was recorded one month after initial formation. The younger age had a significant adverse effect and higher level of education had a positive, but not significant, effect ${ }^{(9)}$.

The results of our research also corroborate those of a study conducted in China. This study made pre-training and feedback (immediately after training) evaluation to demonstrate an improvement in skills of medical students regarding implementation of basic life support (BLS) as well as retention of skills in medical students (330) who were randomized to control and experimental groups. After a lecture (45 $\mathrm{min}$ ) about BLS, all students were evaluated before the practical training (pre-training evaluation). Since difference between skills of both groups was not observed in the pre-training evaluation, a practical training (30 $\mathrm{min})$ in BLS was given only to the experimental group and their skills in BLS were assessed immediately after training (post-test evaluation). A better acquisition of skills was observed in the experimental group in the post-test evaluation $(p<0.001)$ and a better retention of skills also occurred in the experimental group ${ }^{(10)}$.

The importance of practical training was also emphasized in a study with 36 high school students in Sweden $(n=12)$ and the United States $(n=24)$. The objective was also to assess the feasibility of training in CPR using avatars in a software platform game, which was modified for use in training for medical emergencies. By using the MMVW technology, the participants were involved in virtual world scenarios to learn how to treat victims who have suffered cardiac arrest. Debriefings were held after each scenario. The experiences, self-efficacy, and concentration in response to training were analyzed. This type of team training for CPR was shown to be affordable and reliable for this international group of high school students. A high level of appreciation was reported among these adolescents, and their self-efficacy increased significantly. According to the author, the training as described is a new and interesting way of learning CPR, which should be combined with training psychomotor skills in the future, reinforcing the idea that this recourse alone was insufficient and a practical training is necessary ${ }^{(11)}$.

Our research presented results also similar to those of a study performed in Jordan, and this should be highlighted. The researcher assessed the knowledge and confidence of nursing students in applying skills regarding the advanced cardiac life support (ACLS). The study was a randomized controlled (pre- and post-test) experimental design. The experimental group $(n=40)$ participated in an ACLS simulation scenario, PowerPoint presentation $(4 \mathrm{~h})$, and demonstration on a static mannequin, whereas the control group $(n=42)$ participated in only a PowerPoint presentation with demonstration. A paired $t$-test indicated that knowledge about ACLS and confidence increased in both groups. In the experimental group, the knowledge, confidence and skills in ACLS were higher than in the control group. According to the researcher, the traditional training, involving PowerPoint presentation and demonstration on a static mannequin, is an effective teaching strategy. However, simulation is significantly more effective than the traditional formation to help nursing students improve knowledge acquisition, retention, and application of skills in ACLS ${ }^{(12)}$.

Simulation was also used in a US study in which the confidence level was assessed before and after a PCR simulation situation with the use of AEDs. The simulation was performed with 250 nurses who were invited to respond to two different scenarios and each session was followed by debriefing, post-surveys, and evaluation, and the time for $\mathrm{CPR}$ and defibrillation was recorded for analysis. The results show that the participants expressed more confidence in performing the procedure after simulation, and a significant improvement was observed in the time to perform CPR and defibrillation ${ }^{(13)}$.

We used simulation strategies in this research and we evidenced that a large part of the researchers mentioned, who offered practical training for the development of psychomotor skills, also used such teaching strategies in various studies.

Simulation strategies are more realistic and significant forms of learning since they allow students to contact practice earlier, even by simulation ${ }^{(14)}$. The literature is clear when scholars in the subject emphasize that development of this activity is based on the concept of meaningful learning, i.e., they believe that students need to anchor on relevant concepts, previously existing in their structure so that new information makes sense and thus be learned. It is also necessary that they have disposition to learn and the content to be learned be potentially significant, i.e., the more relevant the knowledge acquired for the student life, the more the teaching-learning process develops ${ }^{(15)}$.

We also found criticism to the simulation strategies in a study on highly-structured simulation-based training in the management of emergency situations. Such strategies may have a significant effect on immediate satisfaction and learning. However, 17 former participants in simulations in- 
terviewed in this study described difficulties in adapting to the structured simulation environment and applying knowledge in the uncertain and unstructured clinical world, i.e., the form and the content of these highly-structured courses were insufficient to form the innovative dimension of competence which is required to transfer skills in unstructured emergency situations ${ }^{(16)}$.

Regarding the use of simulation in our research, it can be noticed that the teaching-learning process was built gradually, in stages, as the course was being implemented by the researcher. It started just in Stage 1 (evaluation), in which the students were subjected to a PCR simulation even without knowledge and practical training, thus being mobilized to learning.

According to the literature, mobilization to knowledge consists of enabling the student to a personal learning process, which should be provoked, and the teacher should sensitize him/her in relation to the object of knowledge ${ }^{(17)}$.

Furthermore, it can be seen that the theoretical class with demonstration in mannequin has become a part of the construction in the teaching-learning process, since it was identified as one of the learning stages ${ }^{(18)}$. The cognitive stage is characterized by an intensive mental or intellectual activity, in which the answers related to the very techniques are searched. At this stage, we noticed the students' concern with how to start the procedure, body posture to be adopted, sequence of actions to be carried out, and the actions for implementation-related psychomotor skills to be developed.

Regarding the last evaluation applied after the simulated practical training, we have identified the associative stage $^{(18)}$, which is characterized by a change in the nature of cognitive activity. At this stage, the errors are less frequent and coarse and a refinement occurs in the skills as the students can detect errors and recognize how to improve their performances $^{(6)}$.

Regarding the SKILLS evidenced after the simulated practical training, we found that the students demonstrated to mentally know the sequence of items and consistent attitude and body control. Furthermore, they showed ability to ventilate maintaining pervious airways and cardiac massage at the correct point, satisfactory use of the AED,with gradual and growing improvement in efficiency as the simulated practical training was provided.

\section{CONCLUSION}

After the Theoretical Class (1 $1^{\text {st }}-2^{\text {nd }}$ stage): Regarding SKILLS, a significant improvement was observed in the number of correct answers (28/30 items). However, the index of correct answers of students was $\geq 90 \%$ in only one item (item 5) in the Preliminary Aspects. Regarding KNOWLEDGE, significant improvements were observed in the number of correct answers (39/40 questions).

After the Practical Training ( $2^{\text {nd }}-3^{\text {rd }}$ stage): Regarding SKILLS, a significant improvement was observed in the number of correct answers in all 30 items, with an index of correct answers > 90\% in 26/30 items. Regarding KNOWLEDGE, a significant improvement was observed in the number of correct answers (12/40 questions) in 4/40 questions.

After the Theoretical and Practical Course (theoretical class and practical training; $1^{\text {st }}-3^{\text {rd }}$ stage): Regarding SKILLS, a significant increase was observed in the number of correct answers in all 30 items. Regarding KNOWLEDGE, a significant increase was observed in the number of correct answers in all 40 questions.

This study allowed exploring the teaching-learning process in CPR maneuvers with use of the AED, after using the strategy of theoretical class with practical demonstration after simulated practical training. Given the results obtained in each of them, we infer that both KNOWLEDGE (theory) and SKILLS (practice) are essential in the construction of the teaching-learning process. In this process, we verified that both complement each other and become inseparable in the design of the final product, evidencing the importance of theoretical classes associated with practical classes, i.e., practical training for teaching of psychomotor skills, which promote a more realistic and meaningful learning by using simulation strategies, becoming something relevant in the students' life.

We expect that this research has provided subsidies for the undergraduate students of courses in the health area, who formed the sample in this study, to develop the teaching-learning of KNOWLEDGE and psychomotor SKILLS required for the use of PCR, and professors to use this experience in other courses and stimulate future research on this topic.

\section{RESUMO}

Objetivo: Avaliar o desempenho da habilidade e do conhecimento nas manobras de ressuscitação cardiopulmonar com o uso do desfibrilador externo automático, realizadas pelos estudantes de graduação da área da saúde em três etapas diferentes do processo ensino aprendizagem. Método: Foi aplicado um instrumento de avaliação da habilidade, caracterizado por um modelo padrão "checklist", composto de 30 itens e outro para a avaliação do conhecimento, caracterizado por uma prova escrita composta de 40 questões objetivas. A amostra contou com 84 estudantes. Resultados: Verificou-se que após o curso teórico-prático, na habilidade houve um aumento no número de acertos nos 30 itens e no conhecimento um aumento no número de acertos nas 40 questões. Conclusão: Após a aula teórica com demonstração, na habilidade, somente um dos itens atingiu o índice de acerto $\geq 90 \%$. Já após o treino prático simulado na habilidade, 26 dos itens apresentaram índice de acertos superior a 90\%, evidenciando a importância do treino prático no procedimento em pauta.

\section{DESCRITORES}

Ressuscitação Cardiopulmonar; Desfibriladores; Estudantes de Ciências da Saúde; Educação em Saúde; Aprendizagem; Avaliação. 
RESUMEN

Objetivo: Evaluar el desempeño de la habilidad y el conocimiento en las maniobras de resucitación cardiopulmonar con el uso del desfibrilador externo automático, llevadas a cabo por los estudiantes de pregrado del área de salud en tres etapas distintas del proceso enseñanza aprendizaje. Método: Se aplicó un instrumento de evaluación de la habilidad, caracterizado por un modelo estándar "checklist", compuesto de 30 ítems y otro para la evaluación del conocimiento, caracterizado por una prueba escrita compuesta de 40 cuestiones objetivas. La muestra contó con 84 estudiantes. Resultados: Se verificó que, tras el curso teórico-práctico, en la habilidad hubo un incremento del número de aciertos en los 30 ítems y, en el conocimiento, un incremento del número de aciertos en las 40 cuestiones. Conclusión: Tras la clase teórica, con demostración, en la habilidad solo uno de los ítems alcanzó el índice de acierto $\geq$ 90\%. Después del entrenamiento práctico simulado en la habilidad, 26 de los ítems presentaron índice de aciertos superior al 90\%, evidenciando la importancia del entrenamiento práctico en el procedimiento en cuestión.

\section{DESCRIPTORES}

Resucitación Cardiopulmonar; Desfibriladores; Estudiantes del Área de la Salud; Educación en Salud; Aprendizaje; Evaluación.

\section{REFERENCES}

1. Gonzalez MM, Timerman S, Oliveira RG, Polastri TF, Dallan LA, Araújo S, et al. I Guideline for cardiopulmonary resuscitation and emergency cardiovascular care - Brazilian Society of Cardiology: executive summary.Arq Bras Cardiol. 2013;100(2): 105-13.

2. Pande S, Parate V, Pande S, Sukhsohale N. Evaluation of retention of knowledge and skills life support training imparted to first-year medical students through basicAdvPhysiol Educ. 2014;38(1):42 -5.

3. Montgomery $\mathrm{WH}$. The development of standards and guidelines for Cardiopulmonary resuscitation an emergency cardiac care in the United States. Ann Acad Med. 1992; 21(1):92-6.

4. Scalese RJ, Obeso VT, Issenberg SB. Simulation technology for skills training and competency assessment in medical education. J Gen Intern Med. 2008;23Suppl 1:46-9.

5. Kaakinen J, Arwood E. Systematic review of nursing simulation literature for use of learning theory. Int J NursEducScholarsh. 2009;6: Article 16.

6. Miyadahira AMK. Capacidades motoras envolvidas na habilidade psicomotora da técnica ressuscitação cardiopulmonar: subsídios para o processo ensino-aprendizagem. RevEscEnferm USP. 2001;35(4):366-73.

7. Boaventura AP, Miyadahira AMK. Programa de capacitação em ressuscitação cardiorrespiratória com uso do desfibrilador externo automático em uma universidade. Rev Gaúcha Enferm. 2012;33(1):191-4.

8. Fernandes JMG, Leite ALS, Duarte BSD, Lima JEG, Rivera IR, Mendonça MA.Teaching Basic Life Support to Students of Public and Private High Schools.ArqBrasCardiol. 2014;102(6):593-601.

9. Papalexopoulou K, Chalkias A, Dontas I, Pliatsika P, Giannakakos C, Papapanagiotou P, et al. Education and age affect skill acquisition and retention in lay rescuers after a European Resuscitation Council CPR/AED course. Heart Lung. 2014;43(1):66 -71.

10. Li Q, Zhou RH, Liu J, Lin J, Ma EL, Liang P, et al. Pre-training evaluation and feedback improved skills retention of basic life support in medical students. Resuscitation. 2013;84(9):1274-8.

11. Creutzfeldt J, Hedman L, Heinrichs L, Youngblood P, Felländer-Tsai L. Cardiopulmonary resuscitation training in high school using avatars in virtual worlds: an international feasibility study.J Med Internet Res. 2013;15(1):e9.

12. Tawalbeh LI, Tubaishat A.Effect of simulation on knowledge of advanced cardiac life support, knowledge retention, and confidence of nursing students in Jordan. J Nurs Educ. 2014;53(1):38-44.

13. Delac K, Blazier D, Daniel L, N-Wilfong D. Five alive: using mock code simulation to improve responder performance during the first 5 minutes of a code. CritCareNurs Q. 2013;36(2):244-50.

14. Dornan T, Littlewood S, Margolis AS, Scherpbier A, Spencer J, Ypinazar V. How can experience in: clinical and community settings contribute to early medical education? ABEME systematic review. Med Teach. 2006;28(1):3-18.

15. Masini EPS. Moreira MA. A aprendizagem significativa: a teoria de David Ausubel. São Paulo: Centauro; 2001.

16. Rasmussen MB, Dieckmann P, Barry Issenberg S, Ostergaard D, Soreide E, Ringsted CV. Long-term intended and unintended experiences after Advanced Life Support training. Resuscitation. 2013;84(3):373-7.

17. Anastasiou LGC, Alves LP. Processos de ensinagem na universidade: pressupostos para as estratégias de trabalho em aula. $7^{\mathrm{a}}$ ed. Joinville: UNIVILLE; 2007.

18. Fitts PM, Posner MI. Human performance. Belmont: Brooks Cole; 1967. 